\title{
Melatonin Negatively Correlates with C-Peptide after Food Intake
}

\author{
L. STÁRKA, M. DUŠKOVÁ, B. RÁCZ, K. ŠIMŮNKOVÁ, M. HILL, R. KANCHEVA \\ Institute of Endocrinology, Prague, Czech Republic
}

Received November 12, 2007

Accepted January 28, 2008

On-line February 13, 2008

\section{Summary}

Melatonin plays a key role in the circadian timing system. At present, many other functions of melatonin are known. Question remains whether changes in endogenous melatonin may be associated with food intake. Hence, the levels of melatonin, Cpeptide and glucose were followed during a daily regimen (16 hours) including standardized food intake using commercial kits. The diurnal profiles of the hormones and serum glucose were evaluated using ANOVA with Period and Subject as independent factors. Pearson's correlations and using a multiple stepwise backward regression model consisting of the time factor as a polynomial, and serum C-peptide and glucose assessed the correlations between melatonin and the remaining parameters. Our results showed a significant negative correlation between melatonin and C-peptide. The profile of melatonin was physiological, decreasing after wake-up, showing minor changes during the daytime and increasing in the evening. As documented, lesser alterations were indicated in the course of the melatonin daytime profile, which may reflect periodic food intake. Food intake is not the primary factor influencing the melatonin course. While previous studies have mostly considered the protective effect of melatonin in diabetic subjects, our study brought the results suggesting food intake as a factor contributing to daytime melatonin variation in humans. However, the physiological role of melatonin association with food intake in daytime remains in question and should be further investigated.

\section{Key words}

Melatonin • C-peptide • Food intake • Carbohydrate metabolism • Circadian rhythm

\section{Corresponding author}

L. Stárka, Institute of Endocrinology, Národní třída 8, 11694 Praha 1, Czech Republic. E-mail: Istarka@endo.cz

\section{Introduction}

At present, the role of melatonin is generally known (Illnerová et al. 2000), but many questions still remain concerning the role of the hormone in daytime. Melatonin plays a central role in fine-tuning circadian rhythms in all vertebrate physiology. In addition, it shows a remarkable functional versatility exhibiting antioxidant (direct free radical scavenging and indirect antioxidant activities), oncostatic, anti-aging, immunomodulatory properties and many other functions (Carrillo-Vico et al. 2004).

Melatonin prevents oxidative stress in diabetic subjects as well (Nishida 2005) and protects endothelial cells to hypoxia (Matějovská et al. 2007). In diabetic rats, long term application of melatonin decreased their hyperlipidemia, hyperinsulinaemia, and restored their altered ratio of polyunsaturated fatty acid in serum and tissues, enhanced insulin-receptor kinase and IRS-1 phosphorylation. Studies have also shown possible use of melatonin in the treatment of cholesterol/lipid and carbohydrate disorders (Andersson and Sandler 2001, Klepac et al. 2006, Nishida 2005, Sudnikovich et al. 2007, Yavuz et al. 2003). Although the therapeutic effects of melatonin were exhaustively investigated, the data concerning the physiological role of melatonin in daytime is still deficient. However, results from animal models indicate an anti-insulin effect of melatonin (Ramachandran and Patel 1989) as well as key role of melatonin in carbohydrate metabolism (Alonso-Vale et al. 2004, Borges-Silva et al. 2007). To the best of our knowledge, no information is available on melatonin related to the effects of food intake, such as short-period postprandial sleepiness. Accordingly, we attempted to evaluate whether melatonin correlates with parameters

PHYSIOLOGICAL RESEARCH • ISSN 0862-8408 (print) • ISSN 1802-9973 (online)

(c) 2008 Institute of Physiology v.v.i., Academy of Sciences of the Czech Republic, Prague, Czech Republic

Fax +420 241062 164, e-mail: physres@biomed.cas.cz,www.biomed.cas.cz/physiolres 
rapidly reflecting food intake. Considering the hormonal parameters best reflecting the increase in blood glucose as well as the stability of the analyte, the C-peptide was selected as the optimum indicator.

\section{Methods}

\section{Subjects}

Five women (25-40 years of age, mean 31.6 \pm 2.8 years) were investigated. All of them were premenopausal, non-smokers, healthy and used no medication or hormonal contraception. All subjects were in the follicular phase (3-5 day of menstrual cycle). The volunteers were kept in standardized conditions for five days ( 8 hours sleeping and periodic eating according to standardized menu, which did not differ much from their normal daily program habits). During the trial, all of the volunteers consumed similar food with a standard rate of carbohydrates, proteins and lipids. The study lasted 16 hours, from 5:30 a.m. to 9:30 p.m.

Before the first blood sampling the subjects were given an intravenous cannula (cubital or forearm vein). The first withdrawals of blood were after overnight fasting at 6 a.m. (30 minutes after awaking). The next withdrawals of blood were always one and two hours after eating according to the following schedule (7:15, 8:15, 10:15, 11:15 a.m., 1:15, 2:15, 4:15, 5:15, 7:15, 8:15 p.m.). The last blood taking were 30 minutes before sleep, at 9:30 p.m. Standard plasma tubes with EDTA (5 $\mathrm{ml}$ ) were used.

The Ethical Committee of the Institute of Endocrinology Prague approved the protocol of the study.

\section{Analytical methods}

Samples were centrifuged at $1600 \times \mathrm{g}$ for 15 minutes at $4{ }^{\circ} \mathrm{C}$. Plasma was separated and frozen within half an hour of being drawn from the subject, and was stored at $-30{ }^{\circ} \mathrm{C}$.

C-peptide was measured in serum using ECLIA (elektrochemiluminiscence immunoassay, analyzer Modular E 170, Roche). The measuring range of the kit (defined by the lower detection limit and the maximum of the master curve) was $0.003-13.3 \mathrm{nmol} / 1$ or $0.01-40.0$ $\mathrm{ng} / \mathrm{ml}$ for plasma. Intra- and inter-assay coefficient of variation was $1.5 \%$ and $2.3 \%$, respectively. Blood glucose was measured using the enzymatic reference method with hexokinase (analyzer Cobas Integra 400 plus, Roche). The measuring range of the kit was 0.12-40 $\mathrm{mmol} / \mathrm{l} \quad(2.16-720 \mathrm{mg} / \mathrm{dl})$. Intra-set and inter-set reproducibility was $1.7 \%$ and $2.6 \%$, respectively.

Melatonin was measured using the commercial RIA kit (Laborator Diagnostika Nord GmbH \& Co. KG, Germany, LOT: 5534-2 / EXP: 1.10.2007). The sensitivity for melatonin was $2 \mathrm{pg} / \mathrm{ml}$. The intra-assay and inter-assay coefficient of variation was 9.8-12.1\% and 9.6-12.3\%, respectively.

\section{Statistical data analysis}

Diurnal profiles of hormones and serum glucose were evaluated using repeated measures ANOVA followed by least significant difference multiple comparisons. The ANOVA model consisted of factors Period and Subject. Due to the non-Gaussian data distribution, the variables were treated by a power transformation to attain symmetric distribution and constant variance (Meloun et al. 2000). The outliers were searched using residual analysis but the data was homogeneous when using power transformations.

Relationships between the variables were evaluated using simple and partial correlations after power transformations of original data. In addition, a multiple regression model was built to evaluate the correlations of melatonin with remaining variables. To find outliers in the data, regression diagnostics was applied as described elsewhere (Meloun et al. 2002) but as in the ANOVA model, the data was homogeneous when using power transformations.

\section{Results and Discussion}

As expected, the levels of blood glucose and Cpeptide reflected periodic food intake being in a physiological range (Fig. 1A,B). The profile of melatonin was physiological as well, decreasing after wake-up, showing minor changes during the daytime and increasing in the evening (Fig. 1C). As also documented in Fig. 1C, lesser alterations were indicated in the course of the melatonin daytime profile, which may reflect periodic food intake. Food intake is not the primary factor influencing the melatonin course. This is probably the reason for which the melatonin daytime profile did not show extremes but the inflection points only except the minimum in the 2.15 p.m., which is almost certainly derived from the melatonin diurnal profile. On the other hand, a significant negative correlation between melatonin and C-peptide (Fig. 2A) that was found when using simple pair correlation $(\mathrm{r}=-0.5525, \mathrm{p}<0.0001$, $\mathrm{n}=50)$, partial correlation $(\mathrm{r}=-0.3532, \mathrm{p}<0.02, \mathrm{n}=50)$ and 


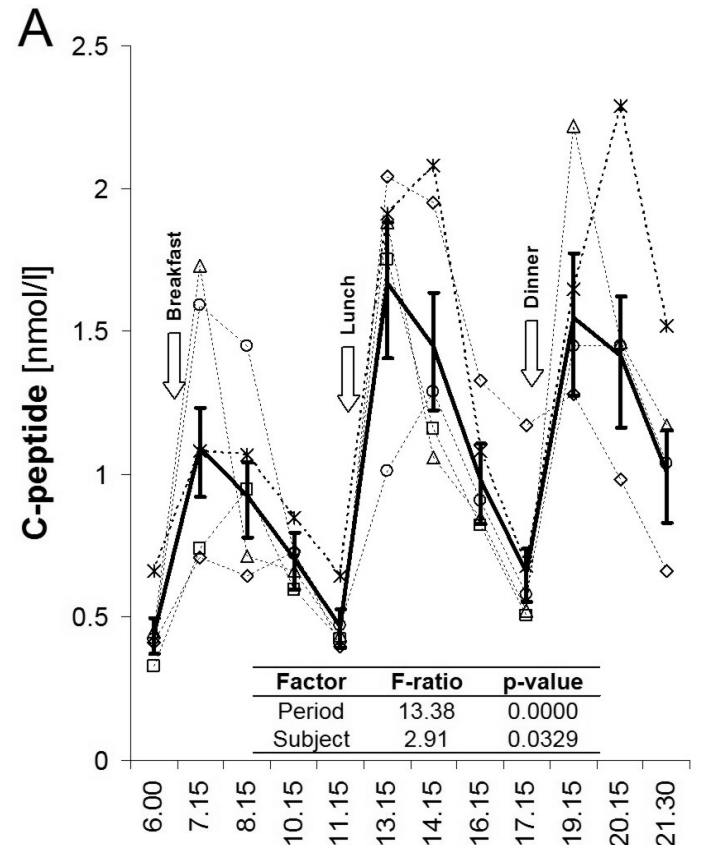

Period [hour]

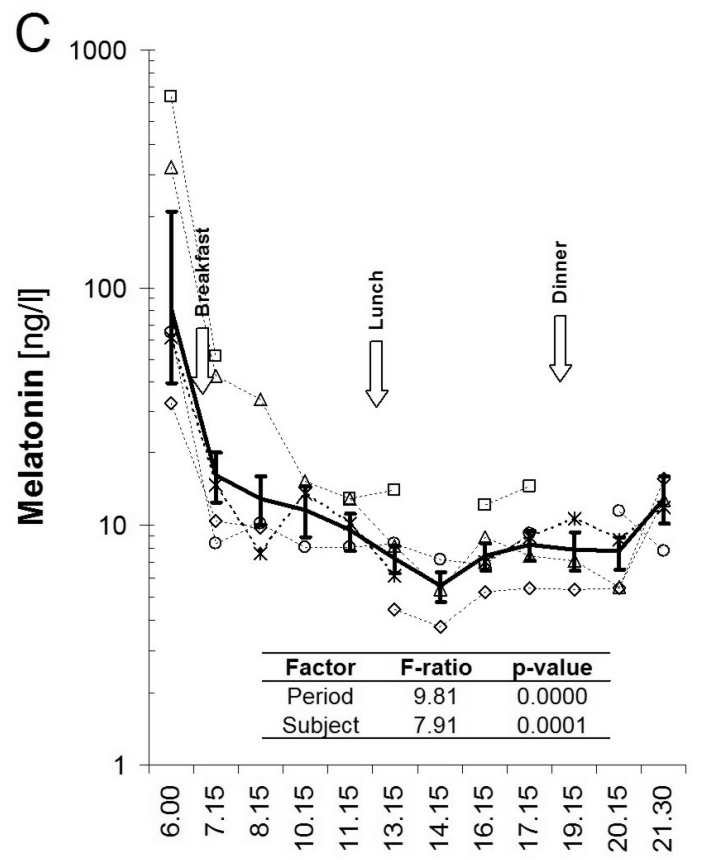

Period [hour]

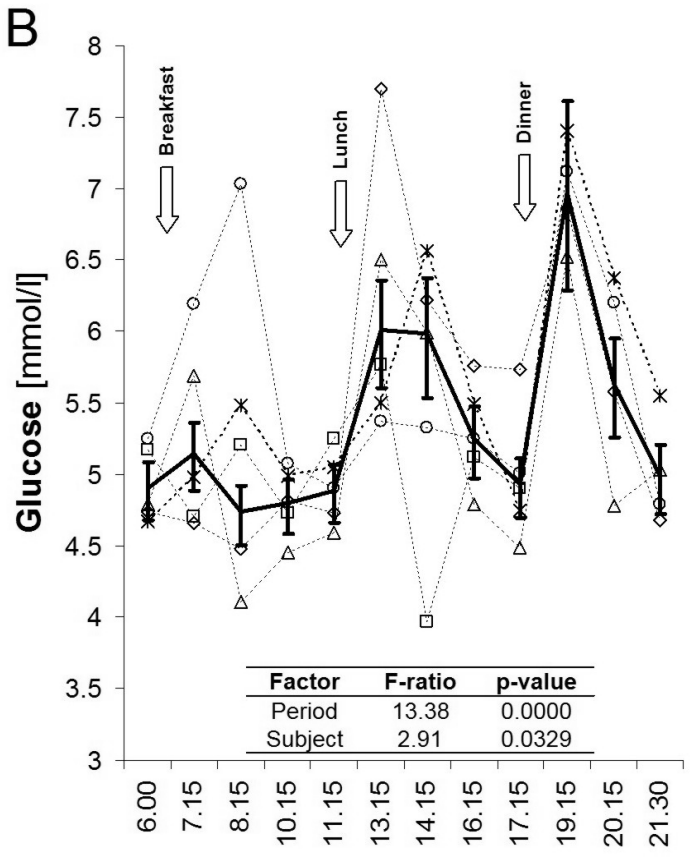

Period [hour]

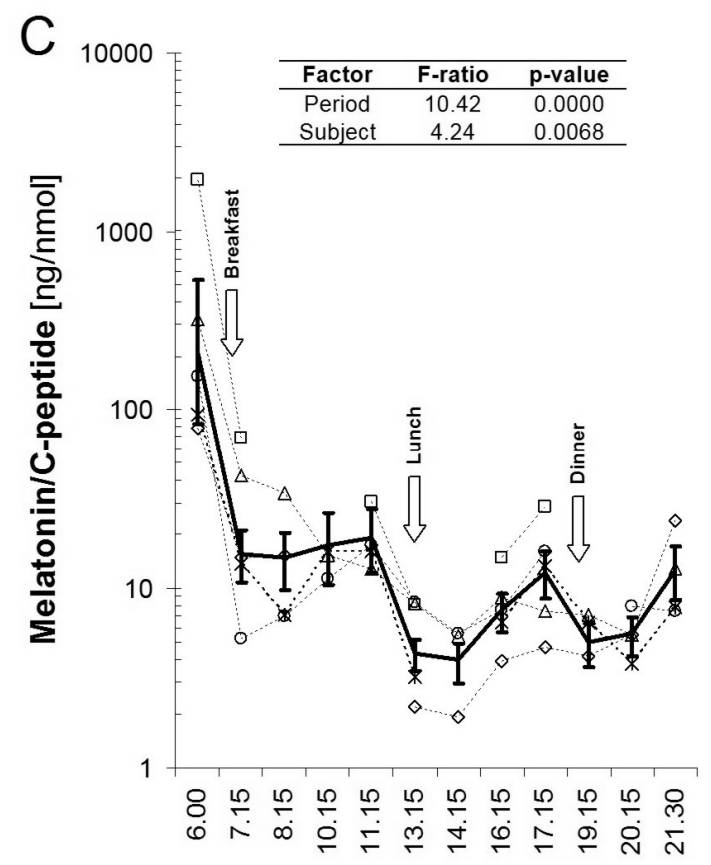

Period [hour]

Fig. 1. Time profiles of serum C-peptide (section A), blood glucose (section B), serum melatonin (section C), and melatonin to Cpeptide ratio (section D) during the 16-hour daytime study. The points connected by thin dashed lines represent individual subjects while the bold line with error bars represent retransformed mean values with their $95 \%$ least significant difference confidence intervals. The group means the error bars of which are not overlapped are significantly different. The individual subjects are distinguished by different markers.

multiple regression model (Table 1) points to a relatively close association between food intake and melatonin levels. In addition, a borderline relationship between melatonin and blood glucose was detected (Fig. 2B), reaching significance for simple pair correlation $(\mathrm{r}=$ $0.4679, \mathrm{p}<0.0006, \mathrm{n}=50$ ) but not when using a multiple regression model (Table 1) or partial correlation with adjustment to constant C-peptide levels $(\mathrm{r}=-0.1265$, $\mathrm{p}=0.3864, \mathrm{n}=50$ ). The correlation between blood glucose and melatonin is weaker probably due to more rapid changes in blood glucose levels when compared to those of C-peptide. As expected, serum C-peptide positively 

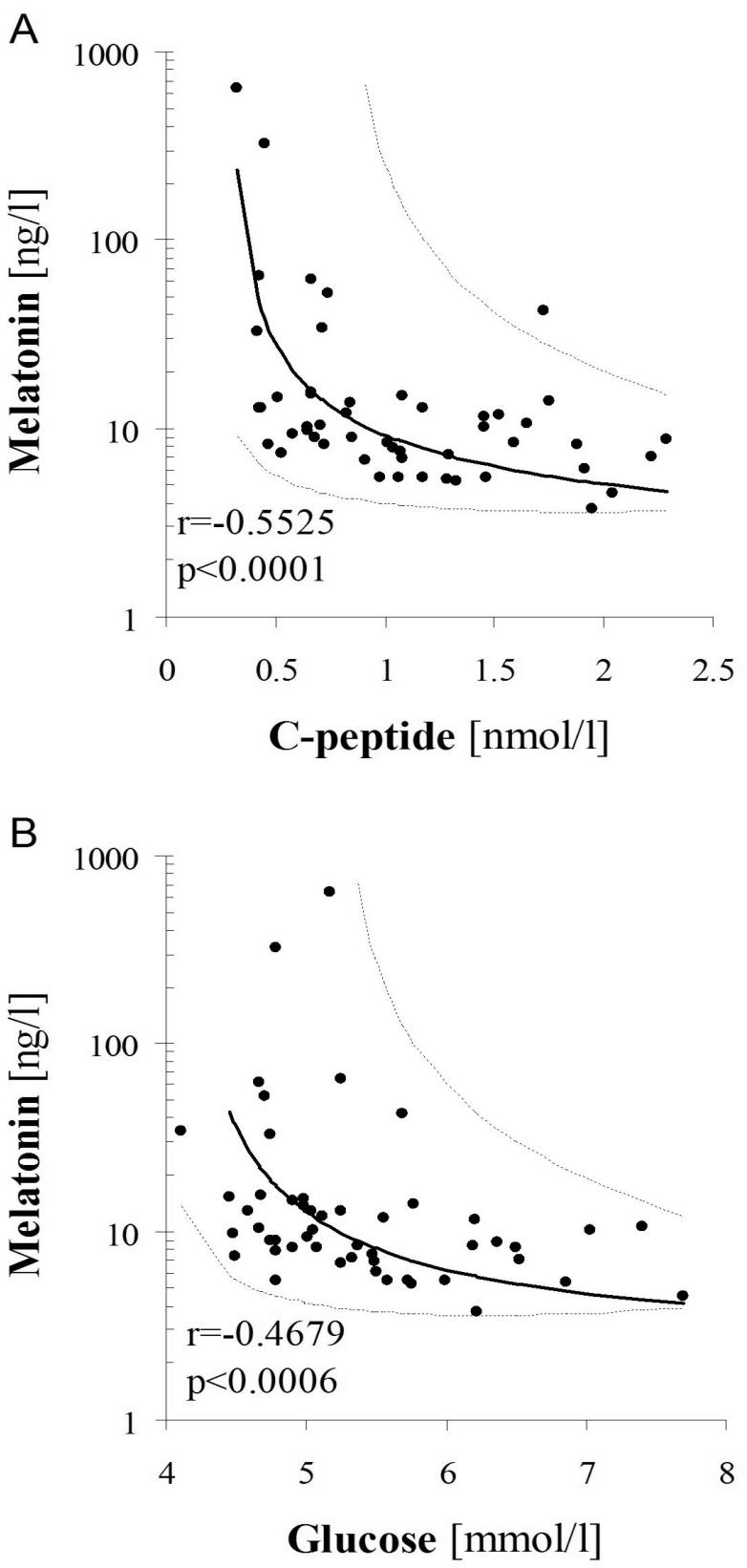

Fig. 2. Relationships C-peptide (section A), blood glucose (section B) and melatonin as evaluated by Pearson's correlation after transformation of both variables for attainment the symmetry and homogeneous variance. The bold curve represent retransformed principal axis while the thin dashed ellipse limits the $95 \%$ confidence ellipsoid.

correlated with blood glucose in both simple pair- and partial correlation adjusted to constant melatonin $(\mathrm{r}=0.713, \mathrm{p}=\mathrm{p}<0.0001, \mathrm{n}=50$ and $\mathrm{r}=0.617, \mathrm{p}=\mathrm{p}<0.0001$, $\mathrm{n}=50$, respectively).

The aforementioned results are in accordance with the hypothesis that was recently published by Peschke et al. (2007). The authors pointed to a possible link between melatonin and diabetes type 2. They investigated the mRNA expression of nuclear orphan receptors and the occurrence of melatonin membrane receptors in pancreatic tissue of both patients suffering from the diabetes type 2 and of healthy controls. An elevated ratio of melatonin membrane receptors (MT1) expression to melatonin membrane receptors MT2 as well as higher levels of melatonin mRNA transcript was found in patients with diabetes type 2 than in control subjects. In addition, the mRNA expression of orphan receptors was also elevated in the diabetic patients.

Several studies have described relationships of artificially induced streptozotocin diabetes in rats to melatonin levels. Stebelová et al. (2007) followed the daily pattern of melatonin concentration in plasma, pineal gland and peripheral organs (pancreas, kidney, spleen, duodenum, colon) in streptozotocin treated rats. With the exception of the colon, the organs showed significantly changing daily profiles of melatonin levels. Except of colon and spleen, the streptozotocin treatment reduced melatonin concentrations in peripheral organs.

In contradiction to our results, a study of Arendt et al. (1982) evaluating the plasma levels of melatonin, cortisol, insulin, C-peptide and GIP (glucose-dependent insulin-releasing peptide) in a 24 hour profile of 12 normal subjects following breakfast at 9 a.m. and subsequent fasting, the authors reported no significant relationship between 24 hour melatonin secretion and basal, or stimulated secretion of gut hormones. The negative result concerning the melatonin levels could be ascribed to long-term fasting when the hormones related to glucose metabolism are in a relative steady state with an absence of abrupt changes induced by periodic food intake as was in our trial.

In conclusion, C-peptide and blood glucose negatively correlate with melatonin. Food intake induces an increase of blood glucose generating insulin secretion and the increase of C-peptide in sequence. The negative relationship between melatonin and C-peptide as well as relatively rapid changes in melatonin levels permits speculation about food as one of the factors influencing daytime melatonin production. The short period of postprandial sleepiness is common in human and other mammals. Hence, the decrease of melatonin levels one hour after meals could be the cause of cessation of postprandial sleepiness and relatively short duration of this period. Hypothetically comes in question also the overall increased postprandial activity of the pineal gland with enhanced secretion of not only melatonin but also of pineal polypeptides, which induce decrease of glycaemia as demonstrated years ago by Milcou (1968). 
Table 1. Relationships between melatonin and stage of the experiment, serum C-peptide (C-pep) and glucose as evaluated by multiple regression.

\begin{tabular}{|c|c|c|c|c|c|c|c|c|}
\hline \multicolumn{9}{|c|}{$\begin{array}{c}\left.\text { Dependent variable: -(Melatonin }{ }^{-0.75}\right) \\
\text { Parameter }^{\mathrm{a}}\end{array}$} \\
\hline & Variable & Unit & Mean & SD & t-stat. & p-value & F-ratio & p-value \\
\hline \multirow{6}{*}{ 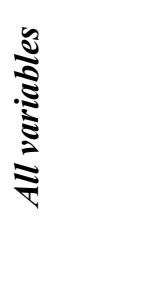 } & Constant & & 0.130 & 0.073 & 1.78 & 0.0813 & ----- & ----- \\
\hline & Time & Hour & -0.051 & 0.009 & -5.50 & 0.0000 & 34.24 & 0.0000 \\
\hline & $\operatorname{Time}^{2}$ & Hour $^{2}$ & 0.002 & 0.000 & 4.95 & 0.0000 & 30.66 & 0.0000 \\
\hline & $\log ($ Срер $)$ & $\log (\mathrm{nmol} / \mathrm{l})$ & -0.041 & 0.021 & -1.93 & 0.0600 & 11.63 & 0.0014 \\
\hline & $-\left(\right.$ Glucose $\left.^{-2}\right)$ & $-\left((\mathrm{mmol} / \mathrm{l})^{-2}\right)$ & -0.918 & 1.104 & -0.83 & 0.4100 & 0.69 & 0.4100 \\
\hline & \multicolumn{8}{|c|}{$\mathrm{R}^{2}=63.2 \%, \mathrm{p}<0.0001$} \\
\hline \multirow{5}{*}{ 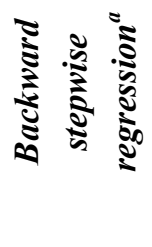 } & Constant & & 0.166 & 0.058 & 2.85 & 0.0065 & ----- & ----- \\
\hline & Time & Hour & -0.052 & 0.009 & -5.61 & 0.0000 & 34.47 & 0.0000 \\
\hline & Time $^{2}$ & Hour $^{2}$ & 0.002 & 0.000 & 5.06 & 0.0000 & 30.87 & 0.0000 \\
\hline & $\log ($ Срер $)$ & $\log (n m o l / l)$ & -0.052 & 0.015 & -3.42 & 0.0013 & 11.71 & 0.0013 \\
\hline & \multicolumn{8}{|c|}{$\mathrm{R}^{2}=62.62 \%, \mathrm{p}<0.0001$} \\
\hline
\end{tabular}

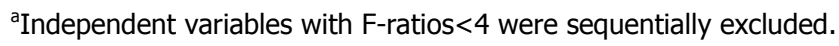

While previous studies mostly considered the protective effect of melatonin in diabetic subjects, our study brought results suggesting that food intake is a factor contributing to daytime melatonin variation in healthy women of reproductive age. However, the physiological role of melatonin in association with food intake in daytime remains in question and should be further investigated.

\section{Conflict of Interest}

There is no conflict of interest.

\section{Acknowledgements}

The study was supported by grant No NR/9055-4 of the Internal Grant Agency of the Ministry of Health of the Czech Republic (IGA MZCR).

\section{References}

ALONSO-VALE MI, ANHE GF, BORGES-SILVA CN, ANDREOTTI S, PERES SB, CIPOLLA-NETO J, LIMA FB: Pinealectomy alters adipose tissue adaptability to fasting in rats. Metabolism 53: 500-506, 2004.

ANDERSSON A K, SANDLER S: Melatonin protects against streptozotocin, but not interleukin-1beta-induced damage of rodent pancreatic beta-cells. J Pineal Res 30: 157-165, 2001.

ARENDT J, HAMPTON S, ENGLISH J, KWASOWSKI P, MARKS V: 24-hour profiles of melatonin, cortisol, insulin, C-peptide and GIP following a meal and subsequent fasting. Clin Endocrinol (Oxf) 16: 89-95, 1982.

BORGES-SILVA CN, TAKADA J, ALONSO-VALE M I, PERES S B, FONSECA-ALANIZ MH, ANDREOTTI S, CIPOLLA-NETO J, PITHON-CURI T C, LIMA F B: Pinealectomy reduces hepatic and muscular glycogen content and attenuates aerobic power adaptability in trained rats. J Pineal Res 43: 96-103, 2007.

CARRILLO-VICO A, CALVO JR, ABREU P, LARDONE PJ, GARCIA-MAURINO S, REITER RJ, GUERRERO J M: Evidence of melatonin synthesis by human lymphocytes and its physiological significance: possible role as intracrine, autocrine, and/or paracrine substance. FASEB J 18: 537-539, 2004.

ILLNEROVÁ H, SUMOVÁ A, TRÁVNÍČKOVÁ Z, JÁČ M, JELÍNKOVÁ D: Hormones, subjective night and season of the year. Physiol Res 49 (Suppl 1): S1-S10, 2000.

KLEPAC N, RUDES Z, KLEPAC R: Effects of melatonin on plasma oxidative stress in rats with streptozotocin induced diabetes. Biomed Pharmacother 60: 32-35, 2006. 
MATĚJOVSKÁ I, BERNÁŠKOVÁ K, KRÝSL D, MAREŠ J: Influence of melatonin pre-treatment and preconditioning by hypobaric hypoxia on the development of cortical photothrombotic ischemic lesion. Physiol Res, 2007 (in press).

MELOUN M, HILL M, MILITKÝ J, KUPKA K: Transformation in the PC-aided biochemical data analysis. Clin Chem Lab Med 38: 553-559, 2000.

MELOUN M, MILITKÝ J, HILL M, BRERETON R G: Crucial problems in regression modelling and their solutions. Analyst 127: 433-450, 2002.

MILCOU S.-M: Role of epiphysis in carbohydrate metabolism [In French] J Annu Diabetol Hotel Dieu. 9: 163-180, 1968.

NISHIDA S: Metabolic effects of melatonin on oxidative stress and diabetes mellitus. Endocrine 27: 131-136, 2005.

PESCHKE E, STUMPF I, BAZWINSKY I, LITVAK L, DRALLE H, MUHLBAUER E: Melatonin and type 2 diabetes - a possible link? J Pineal Res 42: 350-358, 2007.

RAMACHANDRAN AV, PATEL MM: Seasonal differences in glucose tolerance and insulin response of pinealectomized pigeons (Columba livia). J Pineal Res 6: 209-219, 1989.

STEBELOVÁ K, HERICHOVÁ I, ZEMAN M: Diabetes induces changes in melatonin concentrations in peripheral tissues of rat. Neuro Endocrinol Lett 28: 159-165, 2007.

SUDNIKOVICH EJ, MAKSIMCHIK YZ, ZABRODSKAYA SV, KUBYSHIN VL, LAPSHINA EA, BRYSZEWSKA M, REITER RJ, ZAVODNIK IB: Melatonin attenuates metabolic disorders due to streptozotocin-induced diabetes in rats. Eur J Pharmacol 569: 180-187, 2007.

YAVUZ O, CAM M, BUKAN N, GUVEN A, SILAN F: Protective effect of melatonin on beta-cell damage in streptozotocin-induced diabetes in rats. Acta Histochem 105: 261-266, 2003. 